\title{
THE COVID-19 PANDEMIC: A SYSTEMATIC REVIEW OF THE CURRENT EVIDENCE
}

\author{
R. Ghomi, N. Asgari, A. Hajiheydari, R. Esteki, F. Biyabanaki, F. Nasirinasab \\ Isfahan University of medical science, Isfahan, Iran
}

\begin{abstract}
Introduction. An epidemic of Coronavirus Disease 2019 (COVID-19) begun in December 2019 in China, causing primary concern. One of the important issues is its rapid spread around the world. Among the questions raised, disease epidemiology, clinical, laboratory symptoms and radiological findings and treatment of COVID-19 disease have been identified in some studies. But no systematic review on current evidences about COVID-19 has been published. Objective. The aim of this study was to determine the COVID-19 epidemiology, clinical features, diagnosis and treatment. Data sources. We performed a systematic review of the literature, using the keywords: "coronavirus" and "2020", "COVID-19" in databases: Science Direct, PubMed, Springer and Scopus during January 1, 2020 to February 23, 2020. Study Selection. All observational studies, as well as case reports and editorial that published in English were include. Data Extraction. Data on the disease control methods of COVID-19 were extracted by multiple observers. Results. 131 articles were retrieved. After screening by abstract and title, 58 articles were selected for full-text assessment. Of them, 43 were finally included for review. The COVID-19 has spread rapidly and can be transmitted via close human-to-human contact via nasopharyngeal or oropharyngeal droplets. The COVID-19, causing considerable problems, especially in patients with comorbidities and old patients. Fever, cough, sore throat and diarrhea are the main clinical features of this emerging disease. The most common radiological finding is bilateral ground-glass view and Lopinavir and Ritonavir are among the antiviral drugs used. Conclusion. COVID-19 is a new clinical infectious disease and can be a serious problem for health systems. Additional research is needed to elucidate factors that may mediate the pathogenesis of the severe and fatal associated disease.
\end{abstract}

Key words: Coronavirus, SARS-CoV-2, COVID-19.

\section{ПАНДЕМИЯ COVID-19: СИСТЕМАТИЧЕСКИЙ ОБЗОР СОВРЕМЕННЫХ ДАННЫХ}

Гоми Р., Асгари Н., Хаджихейдари А., Эстеки Р., Бийабанаки Ф., Насиринасаб Ф.

Исфаханский университет медицинских наук, Исфахан, Иран

Резюме. Введение. Эпидемия коронавирусного заболевания 2019 г. (COVID-19) началась в декабре 2019 г. в Китае и представляет серьезную проблему. Одним из важных вопросов является ее быстрое распространение во всем мире. В ряде работ были описаны эпидемиология, клинико-лабораторные признаки, рентгенологические характеристики и лечение COVID-19. Однако в настоящее время в доступной литературе отсутствуют систематические обзоры, описывающие накопленные данные по COVID-19. Цель: описание эпидемиологии COVID-19, а также клинических особенностей, диагностики и лечения. Материалы и методы. Проведен систематический обзор литературы по ключевым словам «коронавирус» и «2020», «COVID-19» в базах данных: Science Direct, PubMed, Springer и Scopus за период с 1 января 2020 г. по 23 февраля 2020 г. Отбор типа исследований: все обсервационные исследования, а также описание клинических случаев и редакционных комментариев на английском языке. Извлечение данных: различными наблюдателями

\section{Адрес для переписки:}

Нагрес Асгари

Исфаханский Университет медицинских наук, Исфахан, Иран. E-mail: krezak1990@gmail.com

\section{Contacts:}

Narges Asgari

Shivaye Sharghi st., Khomini shahr, Isfahan, Iran, 9 Dey Hospital, Isfahan University of Medical Sciences.

E-mail: krezak1990@gmail.com

Библиографическое описание:

Гоми Р., Асгари Н., Хаджихейдари А., Эстеки Р., Бийабанаки Ф., Насиринасаб Ф. Пандемия COVID-19: систематический обзор

современных данных // Инфекция и иммунитет. 2020. Т. 10, № 4

С. 655-663. doi: 10.15789/2220-7619-ТCР-1508

(c) Ghomi R. et al., 2020

\section{Citation:}

Ghomi R., Asgari N., Hajiheydari A., Esteki R., Biyabanaki F., Nasirinasab F. The COVID-19 pandemic: a systematic review of the current evidence // Russian Journal of Infection and Immunity = Infektsiya i immunitet, 2020, vol. 10 , no. 4, pp. 655-663. doi: 10.15789/2220-7619-TCP-1508
DOI: http://dx.doi.org/10.15789/2220-7619-TCP-1508 
производилось извлечение данных по методам контроля COVID-19. Результаты. В результате поиска удалось обнаружить 131 статью. После оценки содержания тезисов и названия статей были отобраны 58 работ для анализа полного текста статей, из которых в обзор включены 43 статьи. COVID-19 быстро распространяется и передается при тесном контакте между людьми через назо- и орофарингеальные аэрозоли. COVID-19 вызывал существенные проблемы, особенно у пациентов с сопутствующими заболеваниями и у лиц пожилого возраста. Основными клиническими чертами COVID-19 были лихорадка, кашель, боли в горле и диарея. Наиболее распространенным рентгенологическим признаком заболевания был картина двустороннего матового стекла. Для этиотропной терапии применялись Лопинавир и Ритонавир. Выводы. COVID-19 является новым инфекционным заболеванием и представляет серьезную проблему для здравоохранения. Требуется проведение дополнительных исследований для определения факторов, которые могут опосредовать развитие патогенеза тяжелой и фатальной формы заболевания.

Ключевые слова: коронавирус, SARS-CoV-2, COVID-19.

\section{Introduction}

The illness was first announced on 31 December 2019 that caused by coronavirus [23, 61], was introduced on January 12 by the World Health Organization (WHO) as the novel coronavirus 2019 or 2019 nCoV [14, 74] because Wuhan Viral Pneumonia cases were discovered at the end of 2019. COVID-19 was first identified in Wuhan, China, among a cluster of patients that presented with an unidentified form of viral pneumonia with shared history of visiting the Huanan seafood Market [45].

COVID-19 is a new type of virus that has not been identified before in humans [28]. Coronaviruses are zoonotic and are a large family of viruses that cause illness ranging from the common cold to more severe diseases, such as MERS and SARS [21].

2019-nCoV is considered to be one of the close relatives of SARS-COV, because it is very homologous to SARS-COV. 2019-nCoV was classified by the International Commission on Virus Classification (ICTV) on February 11, 2020 as the severe acute respiratory syndrome Coronavirus 2 (SARS-CoV-2) [29].

The rapid spread of the virus is fueling fears of a global pandemic [17], and over 150 countries have confirmed cases to date, all continents reported confirmed cases of COVID-19. As of March 15, 2020, more than 167,000 confirmed cases have been re-

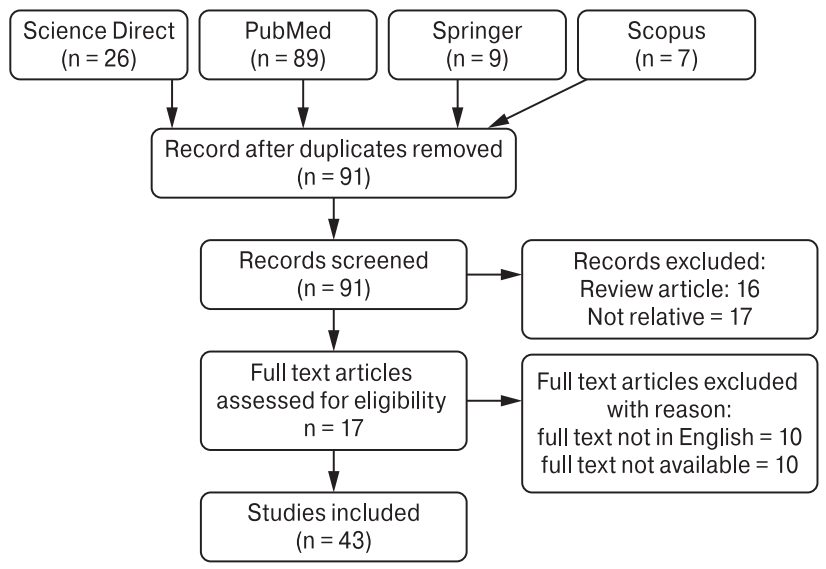

Figure. Study selection and characteristics ported worldwide, with a rapid rise in the number of deaths (6500 deaths and 76,453 recovered) [61]

As expected, several similarities and differences in the epidemiology, clinical features, and management of SARS, MERS, and COVID have been identified [1, 6, 8, 11, 29]. Although the clinical picture of SARS, MERS, and COVID seems to be similar, since early reports, differences were noted [1, 8, 11]. Then, full clinical and epidemiological characterization of disease, as well as their laboratory and image findings and is required.

Therefore, this study was conducted to systematically investigate the published studies on disease epidemiology, clinical, laboratory symptoms and radiological findings and treatment of COVID-19 disease.

Objective. The aim of this study was to determine the COVID-19 epidemiology, clinical features, diagnosis and treatment.

Data sources. This protocol follows the recommendations established by the PRISMA statement [42]. Search was done in order to obtain data using the keywords: "coronavirus" and "2020", "COVID-19" in databases: Science Direct, PubMed, Springer and Scopus during January 1, 2020 to February 23, 2020. Five different researchers independently evaluated search results.

Study selection. All the observational studies, and also case reports, editorial that published in English were included. The preliminary search result was about 131 articles with the term COVID-19 or coronavirus in the title, abstract or text published in English. After reviewing the articles and deleting repetitive articles, to determine whether the article was relevant to the main purpose of the review or not, two authors were reviewed separately titles and abstracts. In the case of ambiguity, the authors referred to the full text for the final decision. Figure displays the process of selecting articles.

Data Extraction: information on the type of publication, the publishing institution, country, year and date of publication and strategies for infection control were extracted independently by five investigators (table 1 displays the Characteristics of the included studies). A sixth researcher checked the article list and data extractions to ensure there were no duplicate articles. 
Table. Characteristics of the included studies on COVID-19, 2020

\begin{tabular}{|c|c|c|c|c|c|c|c|}
\hline Author & Date & Study type & $\mathbf{N}$ & Mean age & Sex & Comorbidities & Mortality \\
\hline Kim & $02 / 24$ & case report & 2 & $35-55$ & female & & \\
\hline H. Chen & $02 / 12$ & case report & 9 & $26-40$ & female & pregnanacy & \\
\hline Bai & $02 / 21$ & case report & 6 & $42-57$ & $\begin{array}{l}66.6 \% \text { female } \\
33.4 \% \text { male }\end{array}$ & & \\
\hline Gostic & $02 / 19$ & modeling strategy & & & & & \\
\hline Y. Zhang & $02 / 19$ & editorial & & & & & $\begin{array}{c}8 \% \\
(\text { male age }>60)\end{array}$ \\
\hline Tong & $02 / 29$ & case report & 7 & 31 & $\begin{array}{c}4 \text { male } \\
3 \text { female }\end{array}$ & & \\
\hline Lim & $02 / 17$ & case report & 1 & 54 & male & & \\
\hline Sabino-Silva & $02 / 17$ & editorial & & & & & \\
\hline Van Cuong & $02 / 18$ & case report & 1 & 25 & female & & \\
\hline Guarner & $02 / 20$ & editorial & & 55 & & & $2-3 \%$ \\
\hline Velavan & $02 / 20$ & editorial & & & & & $2.2 \%$ \\
\hline Lin & $02 / 04$ & case report & 2 & $37(35,39)$ & male & comorbidity & \\
\hline Wong & $02 / 20$ & editorial & & & & & \\
\hline Liem & $02 / 18$ & editorial & & & & & \\
\hline Guan & $02 / 23$ & cohort retrospective & & $47(35-58)$ & $58 \%$ male & hypertension & $1.4 \%$ \\
\hline Y. Yang & $02 / 23$ & cohort retrospective & & & & HTN COPD & \\
\hline Jalavaa & $02 / 25$ & case report & & & & smoker & $2 \%$ \\
\hline Zh. Xu & $02 / 26$ & case report & & & & & \\
\hline J. Zhang & $02 / 29$ & cohort retrospective & 140 & $57(25-87)$ & $50.7 \%$ male & $\begin{array}{c}\text { (64.3\%) comorbidity } \\
\text { HTN (30.0\%); D.M (12.1\%); } \\
\text { drug hypersensitivity (11.4\%); } \\
\text { urticaria (1.4\%); COPD (1.4\%); } \\
\text { smokers (1.4\%) }\end{array}$ & \\
\hline Team & $02 / 20$ & case report & 15 & $43(8-66)$ & $60 \%$ male & HTN/D.M/comorbidity & $2.8 \%$ \\
\hline MacLaren & $02 / 19$ & editorial & & & & & \\
\hline Gao & & editorial & 100 & & & & \\
\hline $\mathbf{X u}$ & $02 / 21$ & cohort retrospective & 55 & $44(3-85)$ & & & \\
\hline X. Chen & $02 / 24$ & editorial & & & & & \\
\hline Y. Zhu & $02 / 26$ & observational & 80 & & & & $2.5 \%$ \\
\hline Ch. Lin & $02 / 26$ & case report & 1 & 61 & & & \\
\hline Cheng & $02 / 20$ & editorial & & Mean $>40$ & & & \\
\hline Wu, Jiong & $02 / 20$ & case report & 1 & 80 & & & \\
\hline Lancet & $02 / 20$ & editorial & & & & & \\
\hline Song & $02 / 20$ & editorial & & & & & \\
\hline Lum & $02 / 20$ & editorial & & & & comorbidity & \\
\hline Kim & $02 / 20$ & observational & & & & & \\
\hline Lai & $02 / 20$ & retrospective review & & $<18$ & & HTN/Cardiac disease/D.M & $\begin{array}{c}\text { Male } \\
\text { Old age }\end{array}$ \\
\hline Habibzadeh & $02 / 20$ & retrospective review & & $49-61$ & & & \\
\hline Qiao & $02 / 20$ & case report & 1 & & & & \\
\hline Albarello & $02 / 20$ & case report & 2 & $66-67$ & & & \\
\hline Yang & $02 / 03$ & retrospective review & 52 & Mean: 60 & & & $\begin{array}{l}5.6 \% \text { (old age } \\
\text { comorbidity) }\end{array}$ \\
\hline Pan & $02 / 03$ & observational & 41 & & & & \\
\hline Q. Chen & $02 / 03$ & observational & 13 & & & & \\
\hline Yang & 02/04 & editorial & & Mean $>60$ & & & \\
\hline Liu & $02 / 18$ & observational & & & & & \\
\hline C. Wu & $02 / 18$ & editorial & & & & & \\
\hline Tian & $02 / 19$ & retrospective review & 262 & 47.5 & & & $0.9 \%$ \\
\hline Qin & $02 / 21$ & retrospective review & 4 & $59.2 \%$ & & & \\
\hline
\end{tabular}




\section{Results}

Mode of transmission. Person-to-person transmission in travelers who are sick or carriers [36, 73], close contact $[15,25,33,37,52,55,69]$, use of shared food container [55], nasopharyngeal or oropharyngeal drops $[30,38,49,69]$ through contact with infectious surfaces or contact with a person [24], isolation of negative pressure and high pollution of personnel [13], also in people who have visited the Hanan animal market [30, 33, 69], contact with wild animals (seafood, wholesale market of chicken and bats, etc.) in the city of Wuhan [15, 40, 67], animal-to-human transmission [15, 33], and then person-to-person transmission [15] were among the factors influencing the spread of the virus. Studies have shown that the virus is not transmitted through breast milk only when breastfeeding by close contact with the mother [46].

Travel from Wuhan to other countries [2], relocation of residents between Hubby and other states [25, 40], and the departure of millions of Chinese from Wuhan for the Chinese New Year Festival [25] led to the release of the new Coronavirus. Some articles have referred to the greater sensitivity of Asian races to viral infections [15], while identifying and treating patients as early as possible can prevent the spread of the disease [41].

Risk factors. In the review, some risk factors affecting the prevalence of COVID-19 disease were identified, including age, underlying diseases, health status, contact history, travel to infected areas and work and living environment. In most studies, the age of people with the disease is 60 years and older [30, $33,38,58,69,74]$. The disease is very rare in children and even if children have it, it occurs with very mild symptoms [60]. The underlying diseases in the elderly are considered as a risk factor, so that $25 \%$ of the elderly with the disease have had underlying disease [40]. The underlying disease in all other age groups is also considered as a risk factor [38], history of hypertension $[25,33,69,71]$, which in some articles includes $15 \%$ of cases [25] and in some cases up to $30 \%$ of cases [71], history of chronic lung disease (COPD) [69, 71], history of diabetes mellitus [33, 71, 74], history of cardiovascular diseases [33] and other chronic diseases [38, 67, 74] as mentioned in some articles, $40 \%$ of cases are related to people with a history of chronic disease [67], severe drug sensitivity and uriticaria are less commonly identified as risk factors [71]. Although pregnancy is not a disease, pregnant women are more exposed to the disease due to physiological changes during pregnancy [10].

COVID-19 is highly contagious and spreads rapidly, so that in some studies, close contact with infected individuals are reported in $60.4 \%$ of cases [54]. In another study, $19 \%$ of new cases of direct contact with approved patients were confirmed [67]. Contact with Wuhan residents caused a high percentage of patients $(72.3 \%)$. It was specified that some people are infected without any previous contact with infectious people or environment [25]. In the Australia $10 \%$ of people were infected without direct contact history [54].

Living in infected places and cities has also been identified as a major risk factor. Living in Wuhan [25, 36, 54], visiting Wuhan market [57], visiting seafood market of Wuhan [67] can also be seen in the history of infected people.

Provincial travels to China and travels from China to other countries led to the spread of COVID-19 [18], so that in the $2^{\text {nd }}$ Epidemiology Report of Australia, $80 \%$ of patients mentioned the history of recent travel to China [18]. The first cases of coronavirus infection in Italy were related to travelers traveling from China to this country [2].

Clinical manifestations. Clinical manifestations in COVID-19 include a wide range of symptoms, some respiratory and some non-specific symptoms. Fever $[2,10,18,25,26,27,36,38,40,47,49$, 54, $55,57,58,63,65,66,67,71]$ has been identified as the most common symptom. In some sources, intermittent fever of [36] or fever over degrees has been reported $[63,66]$. In some studies, the identified patients have not reported a history of fever [10, 37]. Chill alone [18, 36] or chills with fever [47] are other symptoms. Respiratory symptoms include cough [10, $18,19,25,26,33,38,40,49,54,57,58,63,66,71]$, chest pain [57], dizziness [47], dry cough [18, 27, 47, $65,73]$ productive cough [66], nasal congestion [58], restlessness [27, 33], headache [27, 33, 66], weakness [10], muscle cramps [66], sore throat [10, 38, 47, 66], mild shortness of breath [36]. Gastrointestinal symptoms are rare but most important are diarrhea $[10,25$, $27,30,40,66,71]$.

In case of exacerbation of the disease, exacerbation of cough and shortness of breath [32], fever and dry cough and six days after hospitalization, pneumonia symptoms were observed in CT [36]. Symptoms of pneumonia and kidney failure [49], lung involvement 4 days after hospitalization [57], pneumonia [26], 95\% pneumonia and decreasing blood oxygen level [58], respiratory failure (ARDS) [38], shortness of breath [65], pneumonia [18], arrhythmia and shock [52], and finally, the need for mechanical ventilation in the ICU and the progressive symptoms of respiratory failure [2] are among the symptoms of exacerbation of the disease. The average time of intubation of the patient is 6-7 days and the average time of onset of the disease and doctor's visit is 4-5 days [54].

Incubation period. The incubation period of COVID-19 is at least 2 to 7 days [18, 25, 38, 65,74 ] and maximum 14 [65] to 28 days [67] and in some sources 19 days [36]. The average time interval between the onset of symptoms and the time it needs for a person to be admitted is between 4 and 8 days, and from the onset of symptoms to the onset of ARSD, it is 6 to 12 days [18]. 
Diagnosis. In patients with COVID-19 disease, the results of laboratory tests such as $\mathrm{CBC}$ change significantly. The changes of $\mathrm{CBC}$ test results include decreasing white blood cells [57], lymphopenia [5, 10, 25, 27, 71, 73] and neutropenia [38], thrombocytopenia [25], leukopenia [25, 33, 66], and eosinopenia [71]. Disorders of liver enzymes include an increase in ALT, AST [10, 27], inflammatory reactions in the body and as a result, increasing CRP $[5,10,24,26$, $66,71]$ and increasing interleukin [27, 73], as well as changes in the rate of arterial blood gases (ABG) [58] and some nonspecific changes, such as increasing serum ferritin level [27], and increasing procalcitonin [71], are evident.

Changes in the CT-SCAN of the lungs include infiltration of the lungs, which is usually observed at the end of the first week of illness [31], where the lesions are seen bilaterally [67]. Patchy [10, 71] lesions, bilaterally $[15,16,18,22,24,26,37,40,44,47,50$, $51,52]$ ground glass view [10], consolidation [44, 47, 66], bilateral invasive lesions [27, 36, 55], lower lobe involvement [38, 58, 66], and lung alveoli involvement [58] is evident. There are also pulmonary lesions with high absorption characteristics and evidence of lymph node involvement, although there is no diffuse disease. The findings show that COVID-19 disease leads to enlargement of the pulmonary arteries [2].

Treatments. Some articles have referred to the use of antiviral drugs [10, 26, 37] and others have referred to the treatment of antibiotics $[10,25]$ according to the infectious and viral nature of COVID-19 disease. In some articles, the use of antibiotics has been referred for secondary infections. Lopinavir and Ritonavir [32, 33, 36, 40, 58, 60, 73], Remdesivir [58, 60], Oseltamivir [32, 73], Baricitinit [58], Ganciclovir [32, 62], Ribavirin [62] are among the antiviral drugs used. In some cases, immunoglobulin use has been proposed [58], some sources have propsed the use of glucocorticoids [25] and methylprednisolone [58], some pharmacological agents used in the treatment of malaria such as hydroxychloroquine [58], chloroquine sulfate [22] have been used. According to the symptoms and respiratory complications of COVID-19 disease, some patients need respiratory support, including oxygen therapy $[10,15,25$, 27], the need for mechanical ventilation [15, 25] and in some cases even the need for extracorporeal oxygen (ECMO) [25, 41]. Liquid therapy is also used in supportive therapies [15, 27].

Complications of disease. According to the widespread prevalence and nature of the rapid spread of COVID-19 disease, as well as complications and mortality due to this disease, some psychological and social complications such as anxiety $[39,52,74]$ and depression [39, 74], psychological distress [12, 39], PTSD [74], distrust and panic [52], social panic [30] have been reported.

It has been reported that pregnant mothers with COVID-19 have premature birth (36 weeks), baby birth with low weight (less than 2,500 grams), and changes in the baby's myocardial enzymes [10].

The respiratory nature of the disease caused some respiratory complications such as ARDS [2, 33, 67], irritability [12], shock [33], need for hospitalization in the intensive care unit (ICU), pneumothorax [67], and pleural effusion [2]. Following the hospitalization of patients, some complications such as nosocomial infections [67] are proposed. Other non-specific complications of COVID-19 include liver dysfunction [67], renal failure and acute cardiac injury [33, 67].

Other results. At the time of the prevalence of COVID-19, some challenges are proposed, including rumors of fear and the need for credible and valid sources of information, and instant and instantaneous training through public media, which is very helpful $[19,52]$. Paying attention to the health of some vulnerable groups, such as the elderly, especially the elderly who live alone and do not have access to Internet services and education, and the health problems that proposes during quarantine [68] are another challenge in monitoring the health of staff [35]. One of the problems mentioned by health care workers is the problem of working with wearing personal protective equipment (PPE) [12, 74].

\section{Discussion}

Coronavirus is genetically similar to MERS and SARS, and there are similarities between COVID-19 and SARS viruses in terms of diagnosis and treatment, epidemiology, and clinical symptoms.

Compared to SARS and MERS, COVID-19 spreads very fast [64]. The prevalence of SARS and MERS between people occurs through close contact. In COVID-19, the person to person transfer is through coughing and sneezing. But the speed of release is higher in COVID-19 [9]. The similarity of new coronavirus to in person-to-person transfer to the SARS virus is more similar to MERS virus [7].

In many sources, the prevalence of fever has been mentioned in patients with COVID-19 as the most common symptom. Fever can be with or without chill and in COVID-19, dry cough is mentioned as the most common respiratory symptoms. The prevalence of fever and cough are similar to MERS and SARS [19, 53]. And MERS is started with fever and cough and lower parts of lung is involved [19, 43, 53, 70].

According to the results of the present study, breathing shortness has been observed in most patients that cough and shortness of breath is intensified with the continuation of the disease and pneumonia symptoms appear, and in most of these patients, lead to ARDS. Most patients also needed hospitalization, which could be related to a patient's previous underlying illness. A number of them were also hospitalized in the ICU. In severe cases, the breathing shortness is worsened, that mechanical ventilation and ICU hospitalization was needed finally. In SARS epide- 
mics, bilateral airway involvement was seen in the majority of patients. They also experienced a dry, dyspnea cough [72].

In patients with COVID-19, lung CT changes such as lung infiltration and bilateral lesions and patchy and bilateral ground-glass opacity are present, as well as involvement of the lower lobes of lung is created. At SARS, patients with lung CT had ground-glass opacity [29, 52, 67].

In MERS and SARS, diarrhea was seen in 20 to $25 \%$ of patients [59]. In COVID-19, the prevalence of diarrhea is very low.

Lymphopenia was observed in $40 \%$ of the patients. Data from studies conducted during 2003-2002 showed that in SARS, lymphopenia, leukopenia, and thrombocytopenia, an increase in LDH, ALT, AST, and creatine kinase were observed [34, 56]. According to the frequency and prevalence of lymphopenia, it can be concluded that COVID-19 acts on lymphocytes (especially T-lymphocytes, similar to SARS-COV performance).

Patients with COVID-19 have changes in CBC results such as lymphopenia, neutropenia, thrombocytopenia, and leukopenia and eosinopenia. Also in COVID-19, liver enzymes such as ALT and AST increase.

The prevalence (RO) of COVID is 2-3 times, while the prevalence of SARS is $2-5$ times [9].

COVID are more prevalence than SARS and MERS, which led to the globalization of the epidemic [64]. In MERS, older people and with underlying disease had more severe degree of the disease [48], in COVID, the average age of people with the disease is 60 years and older, and $25 \%$ of older people have underlying disease, although there is an underlying disease in other age groups.

In MERS, the average age of the deceased people was 50 years, and $50 \%$ of the patients had underlying disease [48], and in COVID-19, people aged 60 and older were exposed at higher risk for death.
In MERS, hospitalized individuals have a history of contact with infected people or have a history of traveling to infected areas [4], and in COVID-19, transfer from suspected individuals to others has been reported.

PCR is the method of diagnosis in COVID such as SARS and MERS [3] and in COVID such as SARS and MERS, due to pneumonia and changes in the lungs, radiological diagnosis is used as the most important diagnostic tool and to determine the severity of the disease [29]. In MERS, SARS, a combination of Lopinavir and Ritonavir [3, 16] has been used and had minimal clinical complications [16]. Broad-spectrum antiviral drugs, commonly called Remdesivir, have been used to treat SARS and MERS [50, 51]. In COVID, Lopinavir and Ritonavir antiviral drugs have been used for treatment.

Limitations. This review has several limitations. First, still few studies are available for inclusion. It would be better to include as many studies not only from China, once these have been published, to get a more comprehensive understanding of COVID-19. Second, few studies are not available in English or full text.

\section{Conclusion}

COVID-19 is an emerging viral disease that is highly contagious and has spread rapidly across five continents via person-to-person transmission, close contact via nasopharyngeal or oropharyngeal droplets. The COVID-19, causing considerable problems, especially in patients with comorbidities and old patients. Fever, cough, and dyspnea are the main clinical features of this emerging disease. The most common radiological finding is bilateral ground glass view and Lopinavir and Ritonavir are among the antiviral drugs used. Additional research is needed to elucidate factors that may mediate the pathogenesis of the severe and fatal associated disease.

\section{References}

1. Al-Tawfiq J.A., Zumla A., Memish Z.A. Travel implications of emerging coronaviruses: SARS and MERS-CoV. Travel Med. Infect. Dis., 2014, vol. 12, no. 5, pp. 422-428. doi: 10.1016/j.tmaid.2014.06.007

2. Albarello F., Pianura E., Di Stefano F., Cristofaro M., Petrone A., Marchioni L., Palazzolo C., Schininà V., Nicastri E., Petrosillo N., Campioni P., Eskild P., Zumla A., Ippolito G.; COVID 19 INMI Study Group. 2019-novel Coronavirus severe adult respiratory distress syndrome in two cases in Italy: an uncommon radiological presentation. Int. J. Infect. Dis., 2020, vol. 93 , pp. 192-197. doi: 10.1016/j.ijid.2020.02.043

3. Arabi Y.M., Alothman A., Balkhy H.H., Al-Dawood A., Al Johani S., Al Harbi S., Kojan S., Al Jeraisy M., Deeb A.M., Assiri A. M., Al-Hameed F., Al Saedi A., Mandourah Y., Almekhlafi G.A., Sherbeeni N.M., Elzein F.E., Memon J., Taha Y., Almotairi A., Maghrabi K.A., Qushmaq I., Al Bshabshe A., Kharaba A., Shalhoub S., Jose J., Fowler R.A., Hayden F.G., Hussein M.A.; The MIRACLE trial group. Treatment of Middle East Respiratory Syndrome with a combination of lopinavir-ritonavir and interferon- $\beta 1 b$ (MIRACLE trial): study protocol for a randomized controlled trial. Trials, 2018, vol. 19, no. 1: 81. doi: 10.1186/ s13063-017-2427-0

4. Assiri A., Al-Tawfiq J.A., Al-Rabeeah A.A., Al-Rabiah F.A., Al-Hajjar S., Al-Barrak A., Flemban H., Al-Nassir W.N., Balkhy H.H., Al-Hakeem R.F., Makhdoom H.Q., Zumla A.I., Memish Z.A. Epidemiological, demographic, and clinical characteristics of 47 cases of Middle East respiratory syndrome coronavirus disease from Saudi Arabia: a descriptive study. Lancet Infect. Dis., 2013, vol. 13, no. 9, pp. 752-61. doi: 10.1016/S1473-3099(13)70204-4

5. Bai Y., Yao L., Wei T., Tian F., Jin D.Y., Chen L., Wang M. Presumed asymptomatic carrier transmission of COVID-19. JAMA, 2020, vol. 323, no. 14, pp. 1406-1407. doi: 10.1001/jama.2020.2565 
6. Bonilla-Aldana D.K., Quintero-Rada K., Montoya-Posada J.P., Ramírez-Ocampo S., Paniz-Mondolfi A., Rabaan A.A., Sah R., Rodríguez-Morales A.J. SARS-CoV, MERS-CoV and now the 2019-novel CoV: have we investigated enough about coronaviruses? A bibliometric analysis. Travel Med. Infect. Dis., 2020, vol. 33: 101566. doi: 10.1016/j.tmaid.2020.101566

7. Centers for Disease Control and Prevention C. 2019 Novel Coronavirus (2019-nCoV). 2020. URL: https://www.cdc.gov/coronavirus/ 2019-ncov/index.html

8. Chan J.F., Yuan S., Kok K.H., To K.K., Chu H., Yang J., Xing F., Liu J., Yip C.C., Poon R.W., Tsoi H.W., Lo S.K., Chan K.H., Poon V.K., Chan W.M., Ip J.D., Cai J.P., Cheng V.C., Chen H., Hui C.K., Yuen K.Y. A familial cluster of pneumonia associated with the 2019 novel coronavirus indicating person-to-person transmission: a study of a family cluster. Lancet, 2020, vol. 395, no. 10223, pp. 514-523. doi: 10.1016/S0140-6736(20)30154-9

9. Chan-Yeung M., Xu R.H. SARS: epidemiology. Respirology, 2003, vol. 8 (suppl. 1), pp. S9-S14. doi: 10.1046/j.14401843.2003.00518.x. PMID: 15018127; PMCID: PMC7169193.

10. Chen H., Guo J., Wang C., Luo F., Yu X., Zhang W., Li J., Zhao D., Xu D., Gong Q., Liao J., Yang H., Hou W., Zhang Y. Clinical characteristics and intrauterine vertical transmission potential of COVID-19 infection in nine pregnant women: a retrospective review of medical records. Lancet, 2020, vol. 395, pp. 809-815. doi: 10.1016/j.jemermed.2020.04.003

11. Chen N., Zhou M., Dong X., Qu J., Gong F., Han Y., Qiu Y., Wang J., Liu Y., Wei Y., Xia J., Yu T., Zhang X., Zhang L. Epidemiological and clinical characteristics of 99 cases of 2019 novel coronavirus pneumonia in Wuhan, China: a descriptive study. Lancet, 2020, vol. 395, no. 10223, pp. 507-513. doi: 10.1016/S0140-6736(20)30211-7

12. Chen Q., Liang M., Li Y., Guo J., Fei D., Wang L., He L., Sheng C., Cai Y., Li X., Wang J., Zhang Z. Mental health care for medical staff in China during the COVID-19 outbreak. Lancet Psychiatry, 2020, vol. 7, no. 4, pp. e15-e16. doi: 10.1016/S22150366(20)30078-X

13. Chen X., Tian J., Li G., Li G. Initiation of a new infection control system for the COVID-19 outbreak. Lancet Infect Dis., 2020, vol. 20, no. 4, pp. 397-398. doi: 10.1016/S1473-3099(20)30110-9

14. Chen Y., Liu Q., Guo D. Emerging coronaviruses: genome structure, replication, and pathogenesis. J. Med. Virol., 2020, vol. 92, no. 4, pp. 418-423. doi: 10.1002/jmv.25681

15. Cheng Z.J., Shan J. 2019 Novel coronavirus: where we are and what we know. Infection., 2020, vol. 48, no. 2, pp. $155-163$. doi: 10.1007/s15010-020-01401-y

16. Chu C.M., Cheng V.C., Hung I.F., Wong M.M., Chan K.H., Chan K.S., Kao R.Y., Poon L.L., Wong C.L., Guan Y., Peiris J.S., Yuen K.Y.; HKU/UCH SARS Study Group. Role of lopinavir/ritonavir in the treatment of SARS: initial virological and clinical findings. Thorax, 2004, vol. 59, no. 3, pp. 252-256. doi: 10.1136/thorax.2003.012658

17. Cohen E.C. CDC to screen at three US airports for signs of new virus from China. CNN Health. 2020. January 17. URL: https:// edition.cnn.com/2020/01/17/health/wuhan-virus-us-airport-screenings-china-bn/index.html

18. COVID-19 National Incident Room Surveillance Team. COVID-19, Australia: Epidemiology Report 2 (Reporting week ending 19:00 AEDT 8 February 2020). Commun. Dis. Intell. (2018), 2020: 44. doi: 10.33321/cdi.2020.44.14

19. COVID-19: fighting panic with information. Lancet, 2020, vol. 395, no. 10224, p. 537. doi: 10.1016/S0140-6736(20)30379-2

20. De Groot R.J., Baker S.C., Baric R.S., Brown C.S., Drosten C., Enjuanes L., Fouchier R.A., Galiano M., Gorbalenya A.E., Memish Z.A., Perlman S., Poon L.L., Snijder E.J., Stephens G.M., Woo P.C., Zaki A.M., Zambon M., Ziebuhr J. Middle East respiratory syndrome coronavirus (MERS-CoV): announcement of the Coronavirus Study Group. J. Virol., 2013, vol. 87, no. 14, pp. 7790-7792. doi: 10.1128/JVI.01244-13

21. De Wit E., van Doremalen N., Falzarano D., Munster V.J. SARS and MERS: recent insights into emerging coronaviruses. Nat. Rev. Microbiol., 2016, vol. 14, no. 8, pp. 523-534. doi: 10.1038/nrmicro.2016.81

22. Gao J., Tian Z., Yang X. Breakthrough: Chloroquine phosphate has shown apparent efficacy in treatment of COVID-19 associated pneumonia in clinical studies. Biosci. Trends, 2020, vol. 14, no. 1, pp. 72-73. doi: 10.5582/bst.2020.01047

23. Gardner L. Mapping COVID-19. 2020. URL: https://systems.jhu.edu/research/public-health/ncov

24. Gostic K., Gomez A.C., Mummah R.O., Kucharski A.J., Lloyd-Smith J.O. Estimated effectiveness of symptom and risk screening to prevent the spread of COVID-19. Elife, 2020, vol. 9: e55570. doi: 10.7554/eLife.55570

25. Guan W., Ni Z., Hu Y., Liang W., Ou C., He J., Liu L., Shan H., Lei C., Hui D.S.C., Du B., Li L., Zeng G., Yuen K.-Y., Chen R., Tang C., Wang T., Chen P., Xiang J., Li S., Wang J., Liang Z., Peng Y., Wei L., Liu Y., Hu Y., Peng P., Wang J., Liu J., Chen Z., Li G., Zheng Z., Qiu S., Luo J., Ye C., Zhu S., Zhong N., for the China Medical Treatment Expert Group for Covid-19. Clinical characteristics of coronavirus disease 2019 in China. N. Engl. J. Med., 2020, vol. 382, pp. 1708-1720. doi: 10.1056/NEJMoa2002032

26. Guarner J. Three emerging coronaviruses in two decades. Am. J. Clin. Pathol., 2020, vol. 153, no. 4, pp. 420-421. doi: 10.1093/ ajcp/aqaa029

27. Habibzadeh P., Stoneman E.K. The Novel Coronavirus: a bird's eye view. Int. J. Occup. Environ. Med., 2020, vol. 11, no. 2, pp. 6571. doi: 10.15171/ijoem.2020.1921

28. Hernández J.C., Austin Ramzy T. China confirms new coronavirus spreads from humans to humans. The New York Times. 2020. 24 January. URL: https://www.nytimes.com/2020/01/20/world/asia/coronavirus-china-symptoms.html

29. Huang C., Wang Y., Li X., Ren L., Zhao J., Hu Y., Zhang L., Fan G., Xu J., Gu X., Cheng Z., Yu T., Xia J., Wei Y., Wu W., Xie X., Yin W., Li H., Liu M., Xiao Y., Gao H., Guo L., Xie J., Wang G., Jiang R., Gao Z., Jin Q., Wang J., Cao B. Clinical features of patients infected with 2019 novel coronavirus in Wuhan, China. Lancet, 2020, vol. 395, no. 10223, pp. 497-506. doi: 10.1016/ S0140-6736(20)30183-5

30. Jalava K. First respiratory transmitted food borne outbreak? Int. J. Hyg. Environ. Health, 2020, vol. 226: 113490. doi: 10.1016/ j.ijheh.2020.113490

31. Kim H. Outbreak of novel coronavirus (COVID-19): What is the role of radiologists? Eur. Radiol., 2020, vol. 30, pp. 3266-3267. doi: 10.1007/s00330-020-06748-2

32. Kim J.Y., Ko J.H., Kim Y., Kim Y.J., Kim J.M., Chung Y.S., Kim H.M., Han M.G., Kim S.Y., Chin B.S. Viral load kinetics of SARS-CoV-2 infection in first two patients in Korea. J. Korean Med. Sci., 2020, vol. 35, no. 7: e86. doi: 10.3346/ jkms.2020.35.e86 
33. Lai C.C., Shih T.P., Ko W.C., Tang H.J., Hsueh P.R. Severe acute respiratory syndrome coronavirus 2 (SARS-CoV-2) and coronavirus disease-2019 (COVID-19): The epidemic and the challenges. Int. J. Antimicrob. Agents, 2020, vol. 55, no. 3: 105924. doi: 10.1016/j.ijantimicag. 2020.105924

34. Lee N., Hui D., Wu A., Chan P., Cameron P., Joynt G.M., Ahuja A., Yung M.Y., Leung C.B., To K.F., Lui S.F., Szeto C.C., Chung S., Sung J.J. A major outbreak of severe acute respiratory syndrome in Hong Kong. N. Engl. J. Med., 2003, vol. 348, no. 20, pp. 1986-1994. doi: 10.1056/NEJMoa030685

35. Liem A., Wang C., Wariyanti Y., Latkin C.A., Hall B.J. The neglected health of international migrant workers in the COVID-19 epidemic. Lancet Psychiatry, 2020, vol. 7, no. 4: e20. doi: 10.1016/S2215-0366(20)30076-6

36. Lim J., Jeon S., Shin H.Y., Kim M.J., Seong Y.M., Lee W.J., Choe K.W., Kang Y.M., Lee B., Park S.J. Case of the index patient who caused tertiary transmission of COVID-19 infection in Korea: the application of Lopinavir/Ritonavir for the treatment of COVID-19 infected pneumonia monitored by quantitative RT-PCR. J. Korean. Med. Sci., 2020, vol. 35, no. 6: e79. doi: 10.3346/ jkms.2020.35.e79

37. Lin C., Ding Y., Xie B., Sun Z., Li X., Chen Z., Niu M. Asymptomatic novel coronavirus pneumonia patient outside Wuhan: the value of CT images in the course of the disease. Clin. Imaging, 2020, vol. 63, pp. 7-9. doi: 10.1016/j.clinimag.2020.02.008

38. Lin X., Gong Z., Xiao Z., Xiong J., Fan B., Liu J. Novel coronavirus pneumonia outbreak in 2019: computed tomographic findings in two cases. Korean J. Radiol., 2020, vol. 21, no. 3, pp. 365-368. doi: 10.3348/kjr.2020.0078

39. Liu S., Yang L., Zhang C., Xiang Y.T., Liu Z., Hu S., Zhang B. Online mental health services in China during the COVID-19 outbreak. Lancet Psychiatry, 2020, vol. 7, no. 4, pp. e17-e18. doi: 10.1016/S2215-0366(20)30077-8

40. Lum L.H.W., Tambyah P.A. Outbreak of COVID-19 - an urgent need for good science to silence our fears? Singapore Med. J., 2020, vol. 61, no. 2, pp. 55-57. doi: 10.11622/smedj.2020018

41. MacLaren G., Fisher D., Brodie D. Preparing for the most critically ill patients with COVID-19: the potential role of extracorporeal membrane oxygenation. JAMA, 2020, vol. 323, no. 13, pp. 1245-1246. doi: 10.1001/jama.2020.2342

42. Moher D., Liberati A., Tetzlaff J., Altman D.G.; PRISMA Group. Preferred reporting items for systematic reviews and metaanalyses: the PRISMA statement. PLoS Med., 2009, vol. 6, no. 7: e1000097. doi: 10.1371/journal.pmed.1000097

43. Nassar M.S., Bakhrebah M.A., Meo S.A., Alsuabeyl M.S., Zaher W.A. Middle East Respiratory Syndrome Coronavirus (MERS$\mathrm{CoV}$ ) infection: epidemiology, pathogenesis and clinical characteristics. Eur. Rev. Med. Pharmacol, Sci., 2018, vol. 22, no. 15, pp. 4956-4961. doi: 10.26355/eurrev_201808_15635

44. Pan Y., Guan H. Imaging changes in patients with 2019-nCov. Eur. Radiol., 2020, vol. 30, no. 7, pp. 3612-3613. doi: 10.1007/ s00330-020-06713-z

45. Peeri N.C., Shrestha N., Rahman M.S., Zaki R., Tan Z., Bibi S., Baghbanzadeh M., Aghamohammadi N., Zhang W., Haque U. The SARS, MERS and novel coronavirus (COVID-19) epidemics, the newest and biggest global health threats: what lessons have we learned? Int. J. Epidemiol., 2020, vol. 49, no. 3, pp. 717-726. doi: 10.1093/ije/dyaa033

46. Qiao J. What are the risks of COVID-19 infection in pregnant women? Lancet, 2020, vol. 395, no. 10226, pp. 760-762. doi: 10.1016/ S0140-6736(20)30365-2

47. Qin C., Liu F., Yen T.C., Lan X. 18F-FDG PET/CT findings of COVID-19: a series of four highly suspected cases. Eur. J. Nucl. Med. Mol. Imaging, 2020, vol. 47, no. 5, pp. 1281-1286. doi: 10.1007/s00259-020-04734-w

48. Rivers C.M., Majumder M.S., Lofgren E.T. Risks of death and severe disease in patients with Middle East Respiratory Syndrome Coronavirus, 2012-2015. Am. J. Epidemiol., 2016, vol. 184, no. 6, pp. 460-464. doi: 10.1093/aje/kww013

49. Sabino-Silva R., Jardim A.C.G., Siqueira W.L. Coronavirus COVID-19 impacts to dentistry and potential salivary diagnosis. Clin. Oral Investig., 2020, vol. 24, no. 4, pp. 1619-1621. doi: 10.1007/s00784-020-03248-x

50. Sheahan T.P., Sims A.C., Graham R.L., Menachery V.D., Gralinski L.E., Case J.B., Leist S.R., Pyrc K., Feng J.Y., Trantcheva I., Bannister R., Park Y., Babusis D., Clarke M.O., Mackman R.L., Spahn J.E., Palmiotti C.A., Siegel D., Ray A.S., Cihlar T., Jordan R., Denison M.R., Baric R.S. Broad-spectrum antiviral GS-5734 inhibits both epidemic and zoonotic coronaviruses. Sci. Transl. Med., 2017, vol. 9, no. 396: eaal3653. doi: 10.1126/scitranslmed.aal3653

51. Sheahan T.P., Sims A.C., Leist S.R., Schäfer A., Won J., Brown A.J., Montgomery S.A., Hogg A., Babusis D., Clarke M.O., Spahn J.E., Bauer L., Sellers S., Porter D., Feng J.Y., Cihlar T., Jordan R., Denison M.R., Baric R.S. Comparative therapeutic efficacy of remdesivir and combination lopinavir, ritonavir, and interferon beta against MERS-CoV. Nat. Commun., 2020, vol. 11, no. 1, p. 222. doi: 10.1038/s41467-019-13940-6

52. Song P., Karako T. COVID-19: Real-time dissemination of scientific information to fight a public health emergency of international concern. Biosci. Trends, 2020, vol. 14, no. 1, pp. 1-2. doi: 10.5582/bst.2020.01056

53. Srikantiah P., Charles M.D., Reagan S., Clark T.A., Pletz M.W., Patel P.R., Hoekstra R.M., Lingappa J., Jernigan J.A., Fischer M. SARS clinical features, United States, 2003. Emerg. Infect. Dis., 2005, vol. 11, no. 1, pp. 135-138. doi: 10.3201/eid1101.040585

54. Tian S., Hu N., Lou J., Chen K., Kang X., Xiang Z., Chen H., Wang D., Liu N., Liu D., Chen G., Zhang Y., Li D., Li J., Lian H., Niu S., Zhang L., Zhang J. Characteristics of COVID-19 infection in Beijing. J. Infect., 2020, vol. 80, no. 4, pp. 401-406. doi: 10.1016/j.jinf.2020.02.018

55. Tong Z.D., Tang A., Li K.F., Li P., Wang H.L., Yi J.P., Zhang Y.L., Yan J.B. Potential presymptomatic transmission of SARSCoV-2, Zhejiang province, China, 2020. Emerg. Infect. Dis., 2020, vol. 26, no. 5, pp. 1052-1054. doi: 10.3201/eid2605.200198

56. Tsang K.W., Ho P.L., Ooi G.C., Yee W.K., Wang T., Chan-Yeung M., Lam W.K., Seto W.H., Yam L.Y., Cheung T.M., Wong P.C., Lam B., Ip M.S., Chan J., Yuen K.Y., Lai K.N. A cluster of cases of severe acute respiratory syndrome in Hong Kong. N. Engl. J. Med., 2003, vol. 348, no. 20, pp. 1977-85. doi: 10.1056/NEJMoa030666

57. Van Cuong L., Giang H.T.N., Linh L.K., Shah J., Van Sy L., Hung T.H., Reda A., Truong L.N., Tien D.X., Huy N.T. The first Vietnamese case of COVID-19 acquired from China. Lancet Infect. Dis., 2020, vol. 20, no. 4, pp. 408-409. doi: 10.1016/S14733099(20)30111-0

58. Velavan T.P., Meyer C.G. The C.O.V.ID-19 epidemic. Trop. Med. Int. Health, 2020, vol. 25, no. 3, pp. 278-280. doi: 10.1111/ tmi. 13383 
59. Wang C., Horby P.W., Hayden F.G., Gao G.F. A novel coronavirus outbreak of global health concern. Lancet, 2020, vol. 395, no. 10223, pp. 470-473. doi: 10.1016/S0140-6736(20)30185-9

60. Wong J.E.L., Leo Y.S., Tan C.C. COVID-19 in Singapore-current experience: critical global issues that require attention and action. JAMA, 2020, vol. 323, no. 13, pp. 1243-1244. doi: 10.1001/jama.2020.2467

61. World Health Organization (WHO). Coronavirus disease 2019 (COVID-19) Situation Report-66. 2020. URL: https://www.who. int/docs/default-source/coronaviruse/situation-reports/20200326-sitrep-66-covid-19.pdf?sfvrsn=9e5b8b48_2

62. Wu C., Liu Y., Yang Y., Zhang P., Zhong W., Wang Y., Wang Q., Xu Y., Li M., Li X., Zheng M., Chen L., Li H. Analysis of therapeutic targets for SARS-CoV-2 and discovery of potential drugs by computational methods. Acta Pharm. Sin. B., 2020, vol. 10, no. 5, pp. 766-788. doi: 10.1016/j.apsb.2020.02.008

63. Wu J., Wu X., Zeng W., Guo D., Fang Z., Chen L., Huang H., Li C. Chest CT findings in patients with Coronavirus Disease 2019 and its relationship with clinical features. Invest. Radiol., 2020, vol. 55, no. 5, pp. 257-261. doi: 10.1097/RLI.0000000000000670

64. Wu J.T., Leung K., Leung G.M. Nowcasting and forecasting the potential domestic and international spread of the 2019-nCoV outbreak originating in Wuhan, China: a modelling study. Lancet, 2020, vol. 395, no. 10225, pp. 689-697. doi: 10.1016/S01406736(20)30260-9

65. Xu Y.H., Dong J.H., An W.M., Lv X.Y., Yin X.P., Zhang J.Z., Dong L., Ma X., Zhang H.J., Gao B.L. Clinical and computed tomographic imaging features of novel coronavirus pneumonia caused by SARS-CoV-2. J. Infect., 2020, vol. 80, no. 4, pp. 394-400. doi: 10.1016/j.jinf.2020.02.017

66. Xu Z., Li S., Tian S., Li H., Kong L.Q. Full spectrum of COVID-19 severity still being depicted. Lancet., 2020, vol. 395, no. 10228, pp. 947-948. doi: 10.1016/S0140-6736(20)30308-1

67. Yang X., Yu Y., Xu J., Shu H., Xia J., Liu H., Wu Y., Zhang L., Yu Z., Fang M., Yu T., Wang Y., Pan S., Zou X., Yuan S., Shang Y. Clinical course and outcomes of critically ill patients with SARS-CoV-2 pneumonia in Wuhan, China: a single-centered, retrospective, observational study. Lancet Respir. Med., 2020, vol. 8, no. 5, pp. 475-481. doi: 10.1016/S2213-2600(20)30079-5

68. Yang Y., Li W., Zhang Q., Zhang L., Cheung T., Xiang Y.T. Mental health services for older adults in China during the COVID-19 outbreak. Lancet Psychiatry, 2020, vol. 7, no. 4: e19. doi: 10.1016/S2215-0366(20)30079-1

69. Yang Y., Shang W., Rao X. Facing the COVID-19 outbreak: what should we know and what could we do? J. Med. Virol., 2020, vol. 92, no. 6, pp. 536-537. doi: 10.1002/jmv.25720

70. Yin Y., Wunderink R.G. MERS, SARS and other coronaviruses as causes of pneumonia. Respirology, 2018, vol. 23, no. 2, pp. 130137. doi: 10.1111/resp.13196

71. Zhang J.J., Dong X., Cao Y.Y., Yuan Y.D., Yang Y.B., Yan Y.Q., Akdis C.A., Gao Y.D. Clinical characteristics of 140 patients infected with SARS-CoV-2 in Wuhan, China. Allergy, 2020, vol. 75, no. 7, pp. 1730-1741. doi: 10.1111/all.14238

72. Zhang S., Diao M., Yu W., Pei L., Lin Z., Chen D. Estimation of the reproductive number of novel coronavirus (COVID-19) and the probable outbreak size on the Diamond Princess cruise ship: a data-driven analysis. Int. J. Infect. Dis., 2020, vol. 93, pp. 201-204. doi: 10.1016/j.ijid.2020.02.033

73. Zhang Y., Xu J., Li H., Cao B. A novel coronavirus (COVID-19) outbreak: a call for action. Chest, 2020, vol. 157, no. 4, pp. e99e101. doi: 10.1016/j.chest.2020.02.014

74. Zhu Y., Chen L., Ji H., Xi M., Fang Y., Li Y.. The risk and prevention of novel coronavirus pneumonia infections among inpatients in psychiatric hospitals. Neurosci. Bull., 2020, vol. 36, no. 3, pp. 299-302. doi: 10.1007/s12264-020-00476-9

\section{Авторы:}

Гоми Р., Исфаханский Университет медицинских наук, Исфахан, Иран;

Асгари Н., Исфаханский Университет медицинских наук, Исфахан, Иран;

Хаджихейдари А., Исфаханский Университет медицинских наук, Исфахан, Иран;

Эстеки Р., Исфаханский Университет медицинских наук, Исфахан, Иран;

Бийабанаки Ф., Исфаханский Университет медицинских наук, Исфахан, Иран;

Насиринасаб Ф., Исфаханский Университет медицинских наук, Исфахан, Иран.

\section{Authors:}

Ghomi R., 9 Dey Manzariyeh Hospital, Isfahan University of medical science, Isfahan, Iran;

Asgari N., 9 Dey Manzariyeh Hospital, Isfahan University of medical science, Isfahan, Iran;

Hajiheydari A., 9 Dey Manzariyeh Hospital, Isfahan University of medical science, Isfahan, Iran;

Esteki R., 9 Dey Manzariyeh Hospital, Isfahan University of medical science, Isfahan, Iran;

Biyabanaki F., 9 Dey Manzariyeh Hospital, Isfahan University of medical science, Isfahan, Iran;

Nasirinasab F., 9 Dey Manzariyeh Hospital, Isfahan University of medical science, Isfahan, Iran.

Received 12.06.2020

Accepted 31.08.2020 